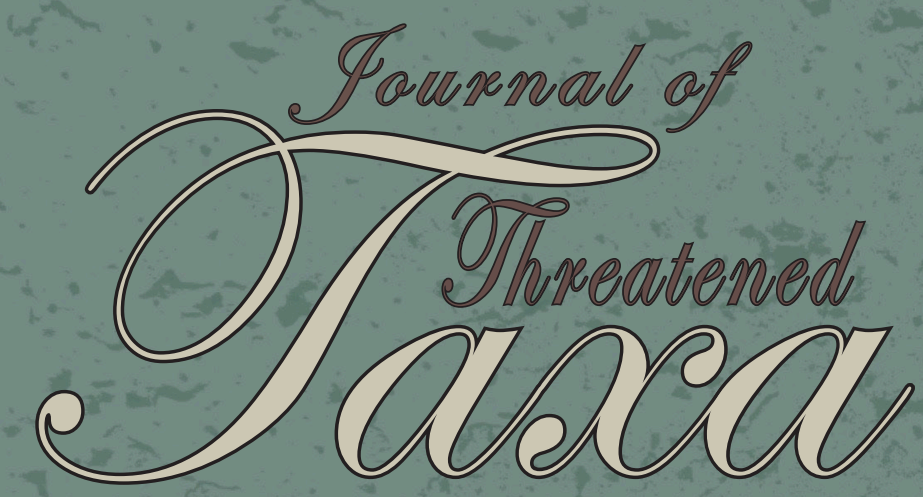

Building evidence for conservation globally
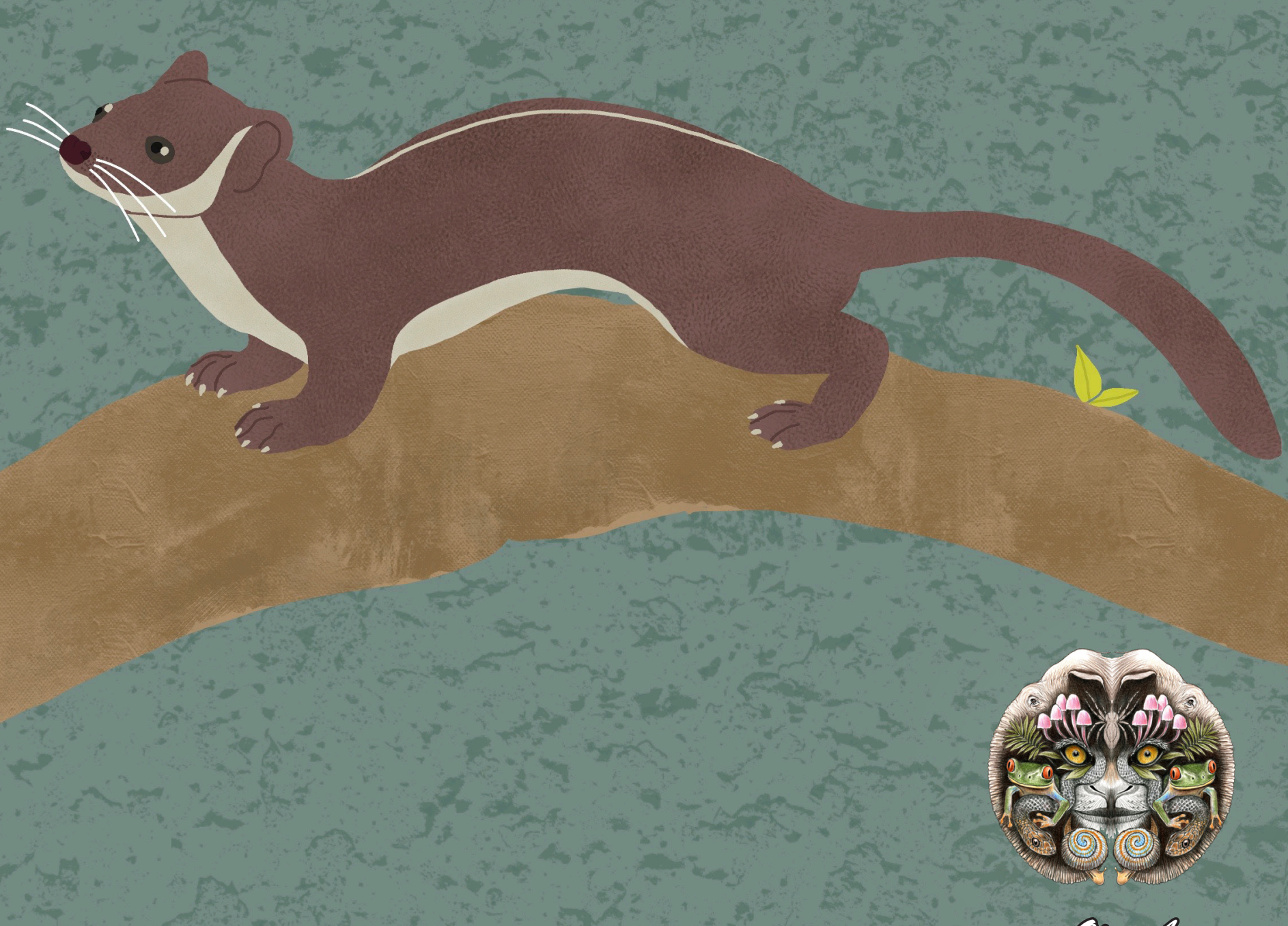

Qpecosecess

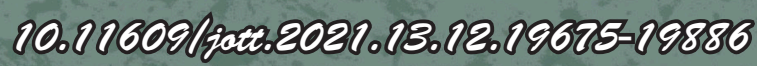
cocosurthreatecredtassararg

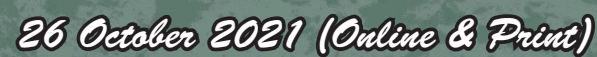

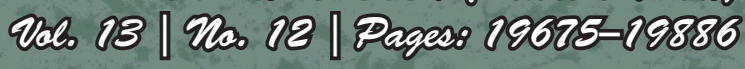




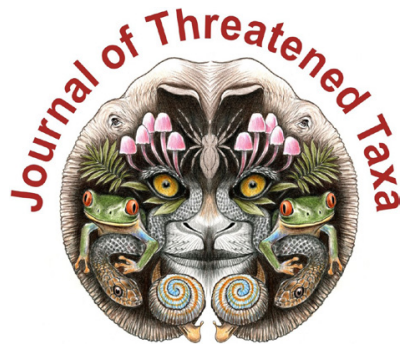

ISSN 0974-7907 (Online); ISSN $0974-7893$ (Print)

Publisher

Host

Wildlife Information Liaison Development Society

www.wild.zooreach.org

Zoo Outreach Organization www.zooreach.org

No. 12, Thiruvannamalai Nagar, Saravanampatti - Kalapatti Road, Saravanampatti, Coimbatore, Tamil Nadu 641035, India

Ph: +91 9385339863 | www.threatenedtaxa.org

Email: sanjay@threatenedtaxa.org

EDITORS

\section{Founder \& Chief Editor}

Dr. Sanjay Molur

Wildlife Information Liaison Development (WILD) Society \& Zoo Outreach Organization (ZOO)

12 Thiruvannamalai Nagar, Saravanampatti, Coimbatore, Tamil Nadu 641035, India

\section{Deputy Chief Edito}

Dr. Neelesh Dahanukar

Noida, Uttar Pradesh, India

\section{Managing Editor}

Mr. B. Ravichandran, WILD/ZOO, Coimbatore, India

\section{Associate Editors}

Dr. Mandar Paingankar, Government Science College Gadchiroli, Maharashtra 442605, India Dr. Ulrike Streicher, Wildlife Veterinarian, Eugene, Oregon, USA

Ms. Priyanka Iyer, ZOO/WILD, Coimbatore, Tamil Nadu 641035, India

Dr. B. A. Daniel, $200 /$ WIID, Coimbatore, Tamil Nadu 641035, India

\section{Editorial Board}

Dr. Russel Mittermeie

Executive Vice Chair, Conservation International, Arlington, Virginia 22202, USA

\section{Prof. Mewa Singh Ph.D., FASc, FNA, FNASc, FNAPsy}

Ramanna Fellow and Life-Long Distinguished Professor, Biopsychology Laboratory, and Institute of Excellence, University of Mysore, Mysuru, Karnataka 570006, India; Honorary Professor, Jawaharlal Nehru Centre for Advanced Scientific Research, Bangalore; and Adjunct Professor, National Institute of Advanced Studies, Bangalore

\section{Stephen D. Nash}

Scientific Illustrator, Conservation International, Dept. of Anatomical Sciences, Health Sciences Center, T-8, Room 045, Stony Brook University, Stony Brook, NY 11794-8081, USA

\section{Dr. Fred Pluthero}

Toronto, Canada

\section{Dr. Priya Davidar}

Sigur Nature Trust, Chadapatti, Mavinhalla PO, Nilgiris, Tamil Nadu 643223, India

\section{Dr. Martin Fisher}

Senior Associate Professor, Battcock Centre for Experimental Astrophysics, Cavendish

Laboratory, JJ Thomson Avenue, Cambridge CB3 OHE, UK

\section{Dr. John Fellowes}

Honorary Assistant Professor, The Kadoorie Institute, 8/F, T.T. Tsui Building, The University of Hong Kong, Pokfulam Road, Hong Kong

\section{Prof. Dr. Mirco Solé}

Universidade Estadual de Santa Cruz, Departamento de Ciências Biológicas, Vice-coordenado do Programa de Pós-Graduação em Zoologia, Rodovia Ilhéus/Itabuna, Km 16 (45662-000)

Salobrinho, Ilhéus - Bahia - Brasil

\section{Dr. Rajeev Raghavan}

Professor of Taxonomy, Kerala University of Fisheries \& Ocean Studies, Kochi, Kerala, India

\section{English Editors}

Mrs. Mira Bhojwani, Pune, India

Dr. Fred Pluthero, Toronto, Canad

Mr. P. Ilangovan, Chennai, India

Web Maintenance

Mrs. Latha G. Ravikumar, ZOO/WILD, Coimbatore, India

\section{Typesetting}

Mr. Arul Jagadish, ZOO, Coimbatore, India

Mrs. Radhika, ZOO, Coimbatore, India

Mrs. Geetha, ZOO, Coimbatore India

\section{Fundraising/Communications}

Mrs. Payal B. Molur, Coimbatore, India

Subject Editors 2018-2020

Fungi

Dr. B. Shivaraju, Bengaluru, Karnataka, India

Dr. R.K. Verma, Tropical Forest Research Institute, Jabalpur, India

Dr. Vatsavaya S. Raju, Kakatiay University, Warangal, Andhra Pradesh, India

Dr. M. Krishnappa, Jnana Sahyadri, Kuvempu University, Shimoga, Karnataka, India

Dr. K.R. Sridhar, Mangalore University, Mangalagangotri, Mangalore, Karnataka, India

Dr. Gunjan Biswas, Vidyasagar University, Midnapore, West Bengal, India

Plants

Dr. G.P. Sinha, Botanical Survey of India, Allahabad, India

Dr. N.P. Balakrishnan, Ret. Joint Director, BSI, Coimbatore, India

Dr. Shonil Bhagwat, Open University and University of Oxford, UK

Prof. D.J. Bhat, Retd. Professor, Goa University, Goa, India

Dr. Ferdinando Boero, Università del Salento, Lecce, Italy

Dr. Dale R. Calder, Royal Ontaro Museum, Toronto, Ontario, Canada

Dr. Cleofas Cervancia, Univ. of Philippines Los Baños College Laguna, Philippines

Dr. F.B. Vincent Florens, University of Mauritius, Mauritius

Dr. Merlin Franco, Curtin University, Malaysia

Dr. V. Irudayaraj, St. Xavier's College, Palayamkottai, Tamil Nadu, India

Dr. B.S. Kholia, Botanical Survey of India, Gangtok, Sikkim, India

Dr. Pankaj Kumar, Kadoorie Farm and Botanic Garden Corporation, Hong Kong S.A.R., China

Dr. V. Sampath Kumar, Botanical Survey of India, Howrah, West Bengal, India

Dr. A.J. Solomon Raju, Andhra University, Visakhapatnam, India

Dr. Vijayasankar Raman, University of Mississippi, USA

Dr. B. Ravi Prasad Rao, Sri Krishnadevaraya University, Anantpur, India

Dr. K. Ravikumar, FRLHT, Bengaluru, Karnataka, India

Dr. Aparna Watve, Pune, Maharashtra, India

Dr. Qiang Liu, Xishuangbanna Tropical Botanical Garden, Yunnan, China

Dr. Noor Azhar Mohamed Shazili, Universiti Malaysia Terengganu, Kuala Terengganu, Malaysia Dr. M.K. Vasudeva Rao, Shiv Ranjani Housing Society, Pune, Maharashtra, India

Prof. A.J. Solomon Raju, Andhra University, Visakhapatnam, India

Dr. Mandar Datar, Agharkar Research Institute, Pune, Maharashtra, India

Dr. M.K. Janarthanam, Goa University, Goa, India

Dr. K. Karthigeyan, Botanical Survey of India, India

Dr. Errol Vela, University of Montpellier, Montpellier, France

Dr. P. Lakshminarasimhan, Botanical Survey of India, Howrah, India

Dr. Larry R. Noblick, Montgomery Botanical Center, Miami, USA

Dr. K. Haridasan, Pallavur, Palakkad District, Kerala, India

Dr. Analinda Manila-Fajard, University of the Philippines Los Banos, Laguna, Philippines

Dr. P.A. Sinu, Central University of Kerala, Kasaragod, Kerala, India

Dr. Afroz Alam, Banasthali Vidyapith (accredited A grade by NAAC), Rajasthan, India

Dr. K.P. Rajesh, Zamorin's Guruvayurappan College, GA College PO, Kozhikode, Kerala, India

Dr. David E. Boufford, Harvard University Herbaria, Cambridge, MA 02138-2020, USA

Dr. Ritesh Kumar Choudhary, Agharkar Research Institute, Pune, Maharashtra, India

Dr. Navendu Page, Wildlife Institute of India, Chandrabani, Dehradun, Uttarakhand, India

Invertebrates

Dr. R.K. Avasthi, Rohtak University, Haryana, India

Dr. D.B. Bastawade, Maharashtra, India

Dr. Partha Pratim Bhattacharjee, Tripura University, Suryamaninagar, India

Dr. Kailash Chandra, Zoological Survey of India, Jabalpur, Madhya Pradesh, India

Dr. Ansie Dippenaar-Schoeman, University of Pretoria, Queenswood, South Africa

Dr. Rory Dow, National Museum of natural History Naturalis, The Netherlands

Dr. Brian Fisher, California Academy of Sciences, USA

Dr. Richard Gallon, llandudno, North Wales, LL30 1UP

Dr. Hemant V. Ghate, Modern College, Pune, India

Dr. M. Monwar Hossain, Jahangirnagar University, Dhaka, Bangladesh

Mr. Jatishwor Singh Irungbam, Biology Centre CAS, Branišovská, Czech Republic.

Dr. lan J. Kitching, Natural History Museum, Cromwell Road, UK

Dr. George Mathew, Kerala Forest Research Institute, Peechi, India

Dr. John Noyes, Natural History Museum, London, UK

For Focus, Scope, Aims, and Policies, visit https://threatenedtaxa.org/index.php/JoTT/aims_scope
For Article Submission Guidelines, visit https://threatenedtaxa.org/index.php/JoTT/about/submissions
For Policies against Scientific Misconduct, visit https://threatenedtaxa.org/index.php/JoTT/policies_various

continued on the back inside cover 


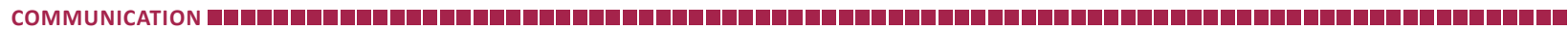

\title{
Diversity of spiders (Arachnida: Araneae) and the impact of pruning in Indian sandalwood plantations from Karnataka, India
}

\author{
S. Padma ${ }^{1}$ (10 \& R. Sundararaj ${ }^{2}$ (1) \\ ${ }^{1,2}$ Forest Protection Division, Institute of Wood Science and Technology, $18^{\text {th }}$ cross, Malleswaram, Bengaluru, Karnataka 560003, India. \\ ${ }^{1}$ padma.rnd@gmail.com (corresponding author) 2rrsundariwst@gmail.com
}

\begin{abstract}
Indian sandalwood Santalum album L. plantations in Karnataka were surveyed to study the diversity and abundance of spider fauna. A total of 1,244 individuals belonging to 56 spider species in 40 genera under 14 families were recorded in the sandalwood plantations. Among the spider families recorded, Araneidae was the most dominant with 15 species in nine genera followed by Salticidae with 13 species in 10 genera, Thomisidae with seven species in four genera, Oxyopidae with four species in three genera, Uloboridae with four species in a genus, and Theridiidae by three species each under three genera. Lycosidae and Sparassidae are represented by two species under two genera each. The families Cheiracanthiidae, Clubionidae, Hersiliidae, Philodromidae, and Pholcidae are represented by a species each. The pruning of sandalwood revealed a significant negative effect on the occurrence and distribution of spiders.
\end{abstract}

Keywords: Ambushers, Araneidae, guild, Orb web, pruning, Salticidae, Santalum album, spider fauna, stalkers, Thomisidae, Uloboridae.

Citation: Padma, S. \& R. Sundararaj (2021).Diversity of spiders (Arachnida: Araneae) and the impact of pruning in Indian sandalwood plantations from Karnataka, India. Journal of Threatened Taxa 13(12): 19762-19772. https://doi.org/10.11609/jott.7514.13.12.19762-19772

Copyright: ( ) Padma \& Sundararaj 2021. Creative Commons Attribution 4.0 International License. JoTT allows unrestricted use, reproduction, and distribution of this article in any medium by providing adequate credit to the author(s) and the source of publication.

Funding: Department of Biotechnology, Ministry of Science and technology, Government of India. No. BT/PR29852/FCB/125/22/2018.

Competing interests: The authors declare no competing interests.

Author details: PADMA, S. is Research scholar in Forest Protection Division, Institute of Wood science and technology, Malleshwaram. Her research interest includes spider and insect ecology, pollination study, disease and pest management, seed germination and wildlife conservation. DR. SUNDARARAJ, R is working as Scientist-G and Head of Forest Protection division, Institute of wood science and technology, Bangalore. He has about 35 years of research experience in the field of protection of wood from bio-deterioration, forest entomology, integrated pest management with special reference to sandalwood and whitefly taxonomy.

Author contributions: SP-carried out the field survey, collection, identification of spiders, analysis of data and prepared the manuscript. RS-guided and assisted Ms. Padma, in every step like, designing and execution of the work and finalizing the manuscript.

Acknowledgements: The authors would like to thank the Dr. K. Sunil Jose, Department of Zoology, Deva Matha College, Kuravilangad, Kottayam, Kerala and Dr. Ambalaparambil V. Sudhikumar, Department of Zoology, Centre for Animal Taxonomy and Ecology, Christ College, Irinjalakuda, Kerala for their valuable guidance and support in identification of spiders. The financial support provided by the Department of Biotechnology, Government of India to conduct this research is gratefully acknowledged.

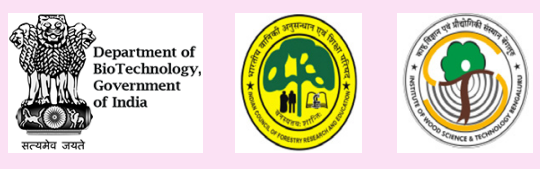




\section{INTRODUCTION}

Spiders are air-breathing carnivorous arthropods and are distributed ubiquitously in the globe except for Antarctica and have adapted to all known ecological environments except air and open sea (Foelix 1996). They are important ecological indicators, used to monitor warning signs for the environment at the earliest and as a biological control agent, since its assemblages have the ability to limit the population growth of arthropod pests and other natural enemies. Spiders are one of the known successful groups of natural predators occupying the agricultural ecosystems, and as efficient predators, they are able to suppress populations of major insect pests (Marc \& Canard 1997). Therefore, relatively higher spider abundance has been considered a requirement for pest control in agricultural systems (Young \& Edwards 1990; Carter \& Rypstra 1995; Sunderland \& Samu 2000).

Globally, spiders include about 49,368 described species in 4,215 genera under 129 families (World Spider Catalog 2021). In India, 1,875 species under 478 genera in 61 families are known (Caleb \& Sankaran 2021). Considering the importance of spiders in integrated pest management strategy, the present study aimed to understand the spider diversity and distribution in sandalwood plantations of Karnataka and assess the impact of pruning of sandalwood in the distribution of spiders.

\section{MATERIALS AND METHODS}

\section{Study area and sampling methods}

An extensive survey was done in sandalwood plantations aged 2-6 years growing in different agroforestry systems in Karnataka (Table 1, Figure 1) for a period of three years from June 2017-May 2020 and sampling was done between $0930 \mathrm{~h}$ to $1130 \mathrm{~h}$. Active searching method of spiders was adopted and handpicked. Spiders were observed from each corner of the plant, from all the branches, flowers, fruits, and even from the ground. Spiders were photographed in their natural habitat and studied under a stereozoom microscope (Nikon SMZ 1500). The information of collection data such as place, date of collection, habitat, the colouration of spider and name of the collector were recorded. The specimens were preserved in vials with $70 \%$ ethyl alcohol and deposited in the Department of Entomology, IWST campus. Spiders were identified based on key morphological features provided by Tikader (1987), taxonomic articles available in the World
Spider Catalog (2021), diagnostic drawings available in Metzner (2021), and with the help of taxonomic experts. Most of the adult spiders were identified to species level and others to genus level.

\section{Impact of pruning on spider density}

To assess the impact of pruning of sandalwood on the diversity and abundance of spiders, a study was undertaken in 2-3 years old plantations of both unpruned and pruned sandalwood during November 2019-January 2020 about 10 hectare in Kolar District, Karnataka. For this purpose, five 50 x 50 m blocks each in pruned and unpruned plantations were marked and from each block, spiders were collected from five trees at random. In unpruned trees, three different habitats (upper, middle, and lower canopies) tree stand were considered and three branches in each canopy were randomly selected for spider collection, the number of arboreal spiders in each tree was counted. In pruned trees, data was collected adopting the same methodology but only from the top canopy as the middle and the lower canopies were lost due to pruning. Three observations were taken at monthly intervals and the data analysed. From the data, comparison was

Table 1. List of Sandalwood plantation localities in Karnataka.

\begin{tabular}{|c|c|c|c|}
\hline & District & Place/Village-Taluk & $\begin{array}{l}\text { Latitude }(N) \text {, } \\
\text { Longitude }(E)\end{array}$ \\
\hline \multirow[b]{2}{*}{1} & \multirow[b]{2}{*}{ Bangalore } & $\begin{array}{l}\text { Institute of wood } \\
\text { science and technology, } \\
\text { Malleshwaram }\end{array}$ & $\begin{array}{l}13.011361 \\
77.570444\end{array}$ \\
\hline & & $\begin{array}{l}\text { Environmental } \\
\text { Management \& Policy } \\
\text { Research Institute, } \\
\text { Doresanipalya }\end{array}$ & $\begin{array}{l}12.899250 \\
77.592222\end{array}$ \\
\hline 2 & Chikballapura & Bagepalli & $\begin{array}{l}13.803028 \\
77.804528\end{array}$ \\
\hline \multirow{2}{*}{3} & \multirow{2}{*}{ Chikkamagaluru } & Bikkaemanae & $\begin{array}{l}13.260722 \\
75.764361\end{array}$ \\
\hline & & Sevapura - Tarikere & $\begin{array}{l}13.703556 \\
75.824500\end{array}$ \\
\hline \multirow{3}{*}{4} & \multirow{3}{*}{ Chamarajanagar } & Arepalya-Kollegal Taluk & $\begin{array}{l}12.083861 \\
77.102889\end{array}$ \\
\hline & & Vadegere - Yelanduru Taluk & $\begin{array}{l}12.039444 \\
77.093667\end{array}$ \\
\hline & & Chikkaluru - Kollegal Taluk & $\begin{array}{l}12.196972 \\
77.282778\end{array}$ \\
\hline \multirow{3}{*}{5} & \multirow{3}{*}{ Kollar } & Agara - Yeldur Taluk & $\begin{array}{l}13.057528 \\
78.432389\end{array}$ \\
\hline & & $\begin{array}{l}\text { Kenchanahalli-Mulbagal } \\
\text { Taluk }\end{array}$ & $\begin{array}{l}13.205889 \\
78.446194\end{array}$ \\
\hline & & $\begin{array}{l}\text { Mudiyanuru - Mulbagal } \\
\text { Taluk }\end{array}$ & $\begin{array}{l}\text { 13.228306, } \\
78.315972\end{array}$ \\
\hline 6 & Kopal & Kushtagi & $\begin{array}{l}\text { 15.759944, } \\
76.196694\end{array}$ \\
\hline \multirow{2}{*}{7} & \multirow{2}{*}{ Tumkur } & $\begin{array}{l}\text { Timmanahalli- } \\
\text { Chikkanayakanahalli Taluk }\end{array}$ & $\begin{array}{l}13.391167 \\
77.199611\end{array}$ \\
\hline & & Bijavara - Madhugiri Taluk & $\begin{array}{l}13.677056 \\
77.236444\end{array}$ \\
\hline
\end{tabular}




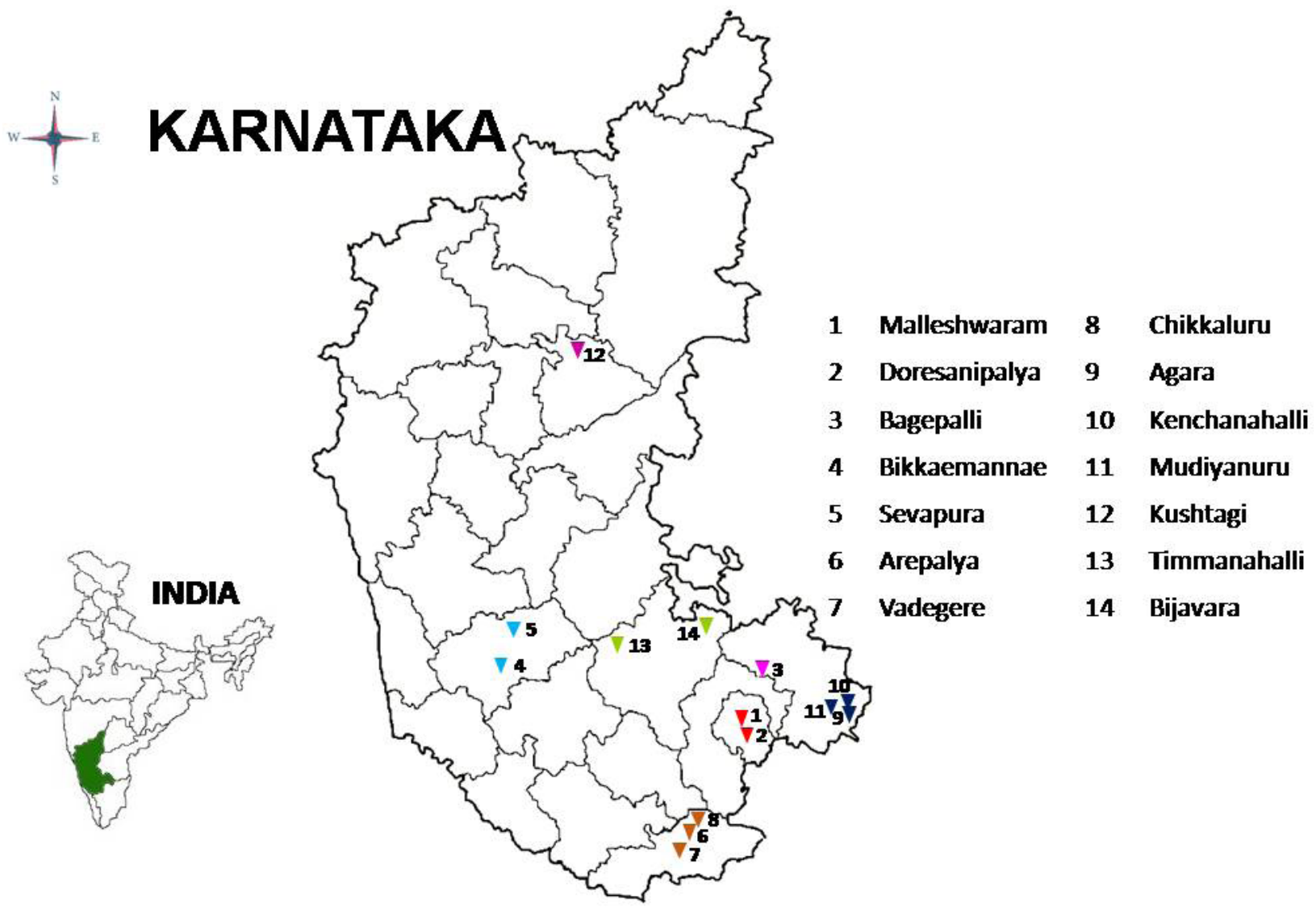

Figure 1. Map of Sandalwood plantations in Karnataka

made between the total spiders collected in unpruned and pruned plantations as well as between the spiders collected only from the top canopy of both the type of plantations by performing one-tailed ANOVA.

\section{Guild classification}

Depending upon the foraging strategies of spiders, they were categorised into eight different ecological guild structures namely, stalkers, ambushers, foliage runners, ground runners, sheet web-builders, tangle weavers, orb weavers, and space web-builders (Uetz et al 1999).

\section{RESULTS}

A total of 1,244 individuals of the 56 species of spiders in 40 genera under 14 families (Table 2) were collected and identified (Table 3 ) from the surveyed sandalwood plantations. Out of the 56 species (Figure $2)$, the family Araneidae (27\%) is the most dominant in terms of species diversity with 15 species in nine genera followed by Salticidae (25\%) with 13 species in 10 genera, Thomisidae (13\%) with seven species in four genera, Oxyopidae (7\%) with four species in three genera, and Uloboridae (7\%) with four species in a single genus. Theridiidae (5\%) is represented by three species under three genera and Lycosidae \& Sparassidae (3\%) with two species in two genera each. The families Cheiracanthiidae, Clubionidae, Hersiliidae Philodromidae, and Pholcidae (2\%) are represented by a species each. In terms of the number of individuals collected, the dominant family was Salticidae with a collection of 366 individuals followed by Araneidae with 350 individuals. Among the species, Telamonia dimidiata was found to be more abundant with a total of 73 individuals followed by Myrmaplata plataleoides, Menemerus bivittatus, Meotipa sahyadri, and Thomisus andamanensis.

The spiders inhabiting the sandalwood plantation fall under eight ecological guilds based on their foraging mode (Figure 3). The majority of the observed spider families belong to 'orb-weavers' category with $36 \%$ dominance, followed by stalkers (30\%), ambushers 
Table 2. Diversity and abundance of spiders in sandalwood plantations.

\begin{tabular}{|c|l|c|c|c|}
\hline & Families & Genus & Species & Individuals \\
\hline 1 & Araneidae & 9 & 15 & 350 \\
\hline 2 & Cheiracanthiidae & 1 & 1 & 17 \\
\hline 3 & Clubionidae & 1 & 1 & 15 \\
\hline 4 & Hersiliidae & 1 & 1 & 17 \\
\hline 5 & Lycosidae & 2 & 2 & 44 \\
\hline 6 & Oxyopidae & 2 & 4 & 57 \\
\hline 7 & Philodromidae & 1 & 1 & 13 \\
\hline 8 & Pholcidae & 1 & 1 & 12 \\
\hline 9 & Salticidae & 11 & 13 & 366 \\
\hline 10 & Sparassidae & 1 & 1 & 37 \\
\hline 11 & Tetragnathidae & 1 & 1 & 16 \\
\hline 12 & Theridiidae & 2 & 3 & 78 \\
\hline 13 & Thomisidae & 5 & 8 & 161 \\
\hline 14 & Uloboridae & 1 & 4 & 74 \\
\hline
\end{tabular}

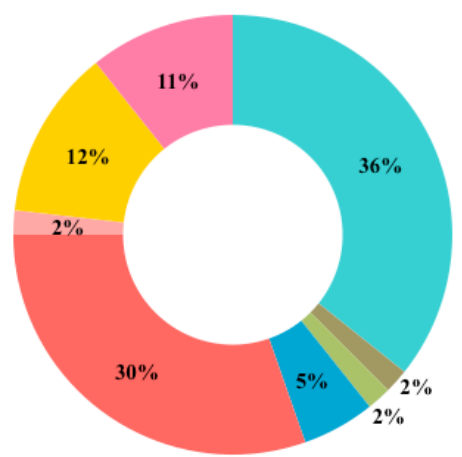

Orb web

Funnel web

Space web builder

- Tangled web

- Stalkers

Ground dweller

Ambushers

Foliage runner

Figure 3. Guilds of spiders from sandalwood plantations.

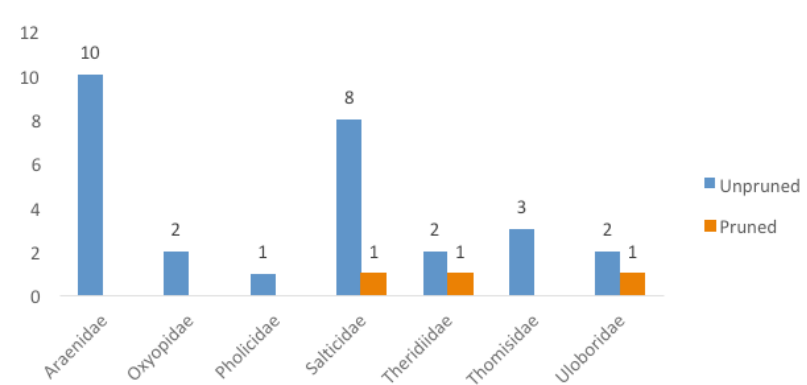

Figure 4. Comparison of spider density (or abundance) in unpruned and pruned plantations of sandalwood.

(12\%), foliage runners (11\%), tangled web (5\%), and $2 \%$ each by ground dwellers, funnel web builders, and space web building spiders.

In the observations from around 10 hectare, unpruned

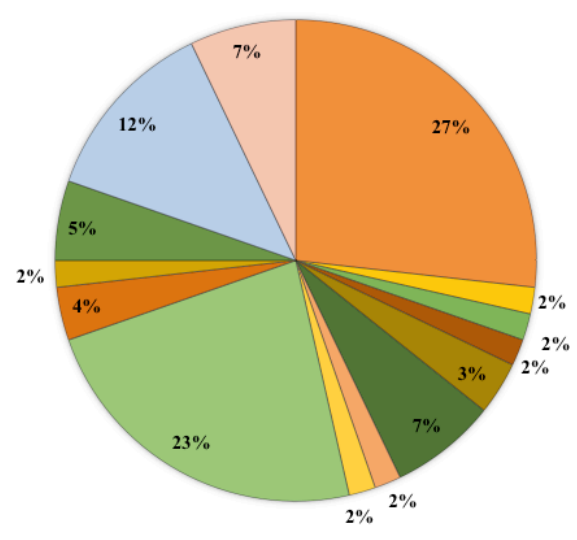

Araenidae

Cheiracanthiidae

Clubionidae

Hersilidae

Lycosidae

Oxyopidae

Philodromidae

$\square$ Pholcidae

Salticidae

Sparassidae

- Tetragnathidae

Theridiidae

$\square$ Thomisidae

Uloboridae

Figure 2. Details of spider families found in sandalwood plantations.

(Image 43) and pruned (Image 44) sandalwood, a total of 149 individuals belonging to 28 species under seven families and 11 individuals belonging to three species under three families were recorded, respectively. The number of spiders collected in unpruned sandalwood trees from upper, middle, and lower were 45 individuals in 11 species, 63 individuals in 21 species, and 44 individuals in 11 species, respectively. In the pruned sandalwood trees, the lower and the middle canopy was lost due to pruning and the number of spiders collected from upper canopy was only 17 individuals of three species (Figure 4). The one-way ANOVA result showed a significant difference in the overall level of diversity and abundance of spiders in pruned and unpruned sandalwood trees, $F(1,28)=171.61, p<0.001$. Also, a significant difference was seen in the upper canopy of unpruned and pruned sandalwood, $F(1,28)=12.55$, $p=0.0014$. Thus, the above result indicates that the interaction of vertical branches and denser vegetation was significant and affected the composition and abundance of spiders.

\section{DISCUSSION}

The present survey is preliminary and the first dealing with spider diversity in sandalwood-based agroforestry ecosystems. Caleb \& Sankaran (2021) reported 1,875 species under 478 genera in 61 families in India out of which 56 species in 40 genera under 14 families were found breeding in sandalwood plantations. This represents $2.986 \%$ and $21.95 \%$ of the total species and families, respectively, recorded in India. The number of families recorded is as high as in other biomes of India. Sandeep et al. (2020) reported 43 species of spiders under 23 families from 21 different fruit crops in Punjab. The 
Table 3. Checklist of spiders in sandalwood plantations.

\begin{tabular}{|c|c|c|}
\hline Family & \multicolumn{2}{|r|}{ Species } \\
\hline \multirow{15}{*}{ Araneidae } & 1 & Arachnura melanura Simon, 1867 (Image 1) \\
\hline & 2 & Araneus mitificus (Simon, 1886) (Image 2) \\
\hline & 3 & Araneus sp. \\
\hline & 4 & Argiope anasuja Thorell, 1887 (Image 3) \\
\hline & 5 & Argiope pulchella Thorell, 1881 (Image 4) \\
\hline & 6 & Cyclosa insulana (Costa, 1834) (Image 5) \\
\hline & 7 & Cyrtophora cicatrosa (Stoliczka, 1869) (Image 6) \\
\hline & 8 & Cyrtophora citricola (Forsskól, 1775) (Image 7) \\
\hline & 9 & Eriovixia laglaizei (Simon, 1877) (Image 8) \\
\hline & 10 & Gasteracantha geminata (Fabricius, 1798) (Image 9) \\
\hline & 11 & Neoscona bengalensis Tikader \& Bal, 1981 (Image 10) \\
\hline & 12 & Neoscona mukerjei Tikader, 1980 (Image 11) \\
\hline & 13 & Neoscona nautica (L.Koch, 1875) \\
\hline & 14 & Neoscona punctigera (Doleschall, 857) (Image 12) \\
\hline & 15 & Nephila pilipes (Fabricius, 1793) (Image 13) \\
\hline Cheiracanthiidae & 16 & Cheiracanthium sp. (Image 14) \\
\hline Clubionidae & 17 & Clubiona sp. \\
\hline Hersiliidae & 18 & Hersilia savignyi Lucas, 1836 (Image 15) \\
\hline \multirow{2}{*}{ Lycosidae } & 19 & Hippasa agelenoides (Simon, 1884) (Image 16) \\
\hline & 20 & Pardosa peudoanulata (Bösenberg \& Strand, 1906) (Image 17) \\
\hline \multirow{4}{*}{ Oxyopidae } & 21 & Hamadruas sp. (Image 18) \\
\hline & 22 & Oxyopes javanus Thorell, 1887 \\
\hline & 23 & Oxyopes sp. (Image 19) \\
\hline & 24 & Peucetia viridana (Stoliczka, 1869) (Image 20) \\
\hline Philodromidae & 25 & Thanatus sp. \\
\hline Pholcidae & 26 & Crossopriza lyoni (Blackwall, 1867) \\
\hline \multirow{13}{*}{ Salticidae } & 27 & Brettus cingulatus Thorell, 1895 (Image 21) \\
\hline & 28 & Carrhotus viduus C.L. Koch, 1846 \\
\hline & 29 & Epeus indicus Prószyński, 1992 (Image 22) \\
\hline & 30 & Hasarius adansoni (Audouin, 1826) \\
\hline & 31 & Hyllus semicupreus (Simon, 1885) (Image 23) \\
\hline & 32 & Menemerus bivittatus (Dufour, 1831) \\
\hline & 33 & Myrmaplata plataleoides (O.P. Cambridge, 1869) (Image 24) \\
\hline & 34 & Plexippus petersi (Karsch, 1878) \\
\hline & 35 & Plexippus paykulli (Audouin, 1826) (Image 25) \\
\hline & 36 & Rhene flavicomans Simon, 1902 (Image 26) \\
\hline & 37 & Rhene flavigera (C.L. Koch, 1846) (Image 27) \\
\hline & 38 & Rhene sp. \\
\hline & 39 & Telamonia dimidiata (Simon, 1899) (Image 28) \\
\hline \multirow{2}{*}{ Sparassidae } & 40 & Heteropoda venatoria (Linnaeus, 1767) (Image 29) \\
\hline & 41 & Olios milletti (Pocock, 1901) (Image 30) \\
\hline Tetragnathidae & 42 & Opadometa fastigata (Simon, 1877) (Image 31) \\
\hline \multirow{3}{*}{ Theridiidae } & 43 & Meotipa sahyadri Kulkarni, Vartak, Deshpande \& Halali, 2017 (Image 32) \\
\hline & 44 & Nihonhimea mundula (L.Koch, 1872) (Image 33) \\
\hline & 45 & Parasteatoda sp. \\
\hline \multirow{7}{*}{ Thomisidae } & 46 & Loxobates sp. (Image 34) \\
\hline & 47 & Misumena sp. (Image 35) \\
\hline & 48 & Thomisus andamanensis Tikader, 1980 (Image 36) \\
\hline & 49 & Thomisus bulani Tikader, 1960 \\
\hline & 50 & Thomisus lobosus Tikader, 1965 (Image 37) \\
\hline & 51 & Thomisus projectus Tikader, 1960 (Image 38) \\
\hline & 52 & Tmarus sp. \\
\hline \multirow{4}{*}{ Uloboridae } & 53 & Uloborus sp. 1 (Image 39) \\
\hline & 54 & Uloborus sp. 2 (Image 40) \\
\hline & 55 & Uloborus sp. 3 (Image 41) \\
\hline & 56 & Uloborus sp. 4 (Image 42) \\
\hline
\end{tabular}


difference in spider fauna can be related to different time frames and methods of collection. Even environmental factors like the type of vegetation, seasonality, spatial heterogeneity, predation, prey occurrence etc. can affect species diversity (Riechert \& Bishop 1990) and spiders are extremely sensitive to small changes in the habitat structure, complexity, and microclimate characteristics. Their abundance and distribution may vary from one geographic area to another (Downie et al. 1999). Spiders are polyphagous, feed on a variety of available prey even on the egg, larva/nymph, as well as adult stages of insects (Sandeep et al. 2020). Predatory spiders found breeding in the sandalwood-based agroforestry ecosystems serve as a source of successive predation against pests of sandalwood.

Most spiders exhibit excellent colouration and protective camouflage. The ant mimicking spider $M$. plataleoides and Hersilia savignyi resemble the bark of trees. Thomisid spiders commonly called ambushers which are "sit and wait" type of prey hunting spiders, sit on the flowers and have attractive colouration similar to the flower in which they hide. In contrast to this Hippasa agelenoides construct funnels/tunnels? in ground strata, hide at the small end and rush out and grab the prey (Pooja et al. 2019). Further, the difference in spider fauna is based on the vertical segregation of the foraging heights. Some spiders might prefer living in the uppermost parts of the plant, like Nephila pilipes and Gasteracantha geminata, while a few spiders like Pardosa pseudoannulata and $H$. agelenoides are usually found on the ground.

Arboreal spider assemblages assessed by the abundance-based measure showed a significant difference between unpruned and pruned sandalwood. Even the upper canopy inhabiting spiders were significantly less in pruned than unpruned sandalwood; this might be due to non-availability of nutritional resources and required breeding resources in the pruned trees. Pruning of sandalwood was found to have adverse effects on the diversity and abundance of spiders. Unpruned sandalwood is not only healthy, the lateral branches support erectness of the main stem and protect the tree from adverse conditions like high winds, rainstorms, and intense sunlight. It also supports the survival and existence of diverse living organisms including spiders. The presence of lateral branches increase the probability of dispersal of spiders by ballooning; also the canopy provides a conducive environment to hide from its own predators and in successful predation on prey. Pruned plants devoid of lower lateral branches having flatter branches with shorter vertical spread might increase the exposure of spiders to visually foraging predators (e.g., birds), it also narrows their habitat and the availability of natural food resources by decreasing the occurrence of prey, thus it negatively correlated with spider densities. In a given habitat, the biomass of vegetation and prey availability were the best predictions of spider abundance (Halaj et al. 1998). Rypstra (1986) documented a strong positive relationship between the diversity of web-building spiders and vegetation structural diversity across several habitats. It corroborated the dominance of orb-weaving spiders in unpruned sandalwood and enlightens the importance of branches and the natural growth of sandalwood for the occurrence of web-building spiders. Web-building spiders are stationary predators that wait for prey to approach near them. Their abundance is directly related to the physical architecture of the vegetation (Greenstone 1984). The chance of their occurrence in pruned trees is almost eliminated except fora few species of Uloboridae with a fewer number of individuals. Also, the pruned trees are susceptible to harsh wind effects and rainstorms, making them unsuitable for web-building spiders. Similarly, the occurrence of stalkers the second dominant guild, which actively jump over the prey for feeding, is directly related to the prey availability and shaded environment which hides them from other larger predators (Pooja et al. 2019). This is applicable to the rest of the spiders and their abundance. Many earlier studies confirmed that the diversity and complexity of the vegetation positively affects the abundance of spiders (Sudhikumar et al. 2005; Orguri et al. 2014; Ossamy et al. 2016).

Sundararaj et al. (2018) documented more species of insect pests and natural enemies from more diversified areas of sandalwood cultivation but with less severity of the infestations and not having requirement of the insecticidal application. Also, the plant diversity regulates insect herbivore populations by favouring the abundance and efficacy of associated natural enemies (Altieri \& Letourneau 1984). Due to the pruning of sandalwood trees, the mobile ecosystem service providers like pollinators do not get a conducive environment for making their colonies and in combination with extensive applications of agrochemicals have a negative effect on the foraging ability and lifespan of pollinators and their resilience which leads to a colossal loss of pollination and apiculture (Sundararaj et al. 2020). Agroforestry practices enhance habitat diversification, increase soil productivity, support native fauna in agricultural landscapes and more resilience towards pests (Torres et al. 2015). The presence of fringe areas 


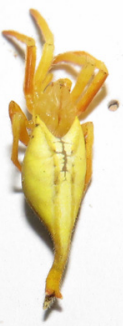

Image 1. Arachnura melanura

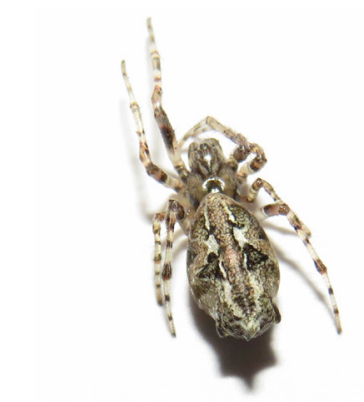

Image 5. Cyclosa insulana

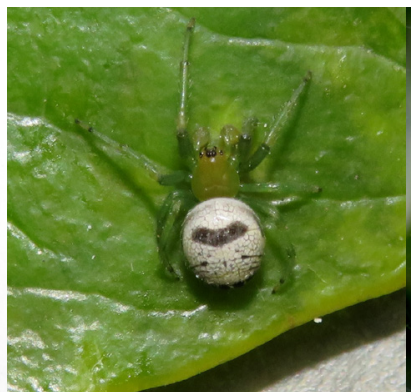

Image 2. Araneus mitificus

Image 3. Argiope anasuja

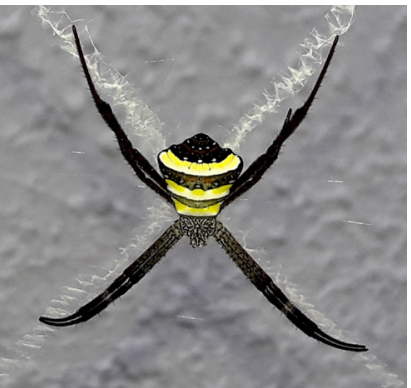

Image 4. Argiope pulchella

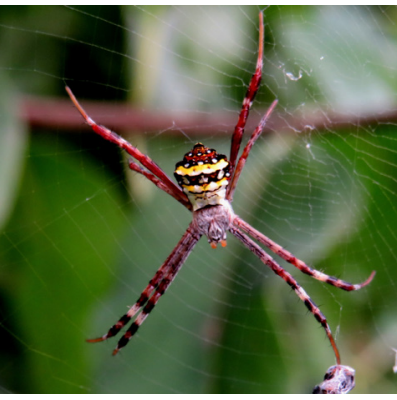

Image 6. Cyrtophora cicatrosa

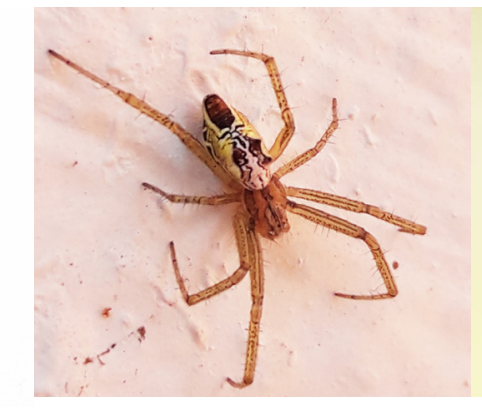

Image 7. Cyrtophora citricola

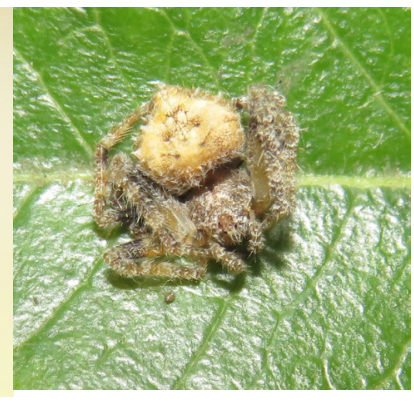

Image 8. Eriovixia laglaizei

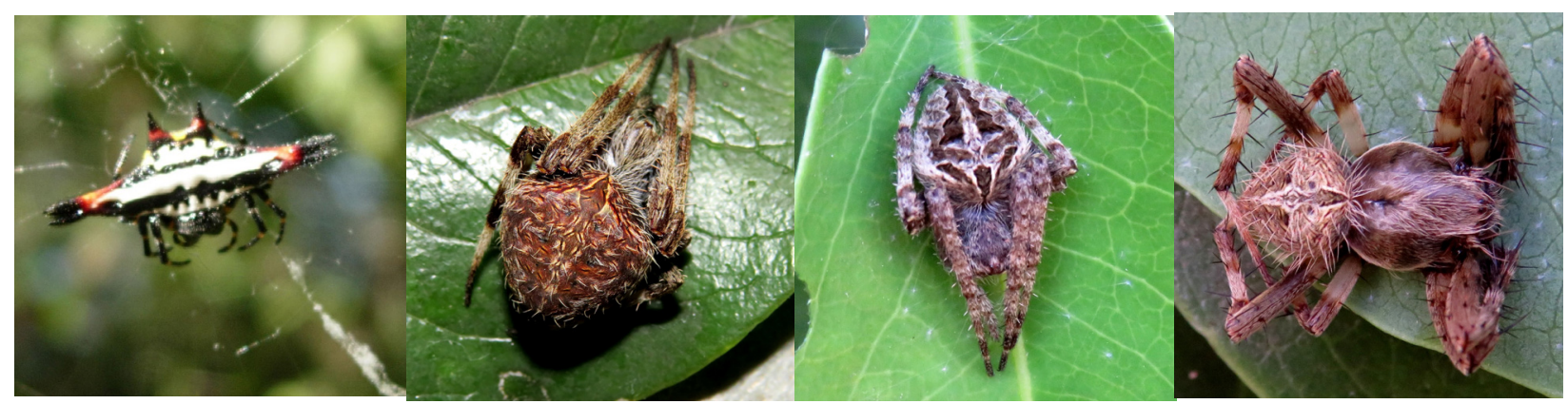

Image 9. Gasteracantha geminata Image 10. Neoscona bengalensis Image 11. Neoscona mukerjei

Image 12. Neoscona punctigera

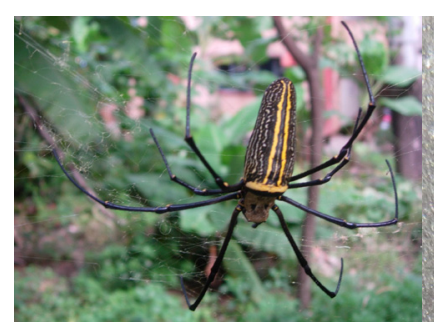

Image 13. Nephila pilipes
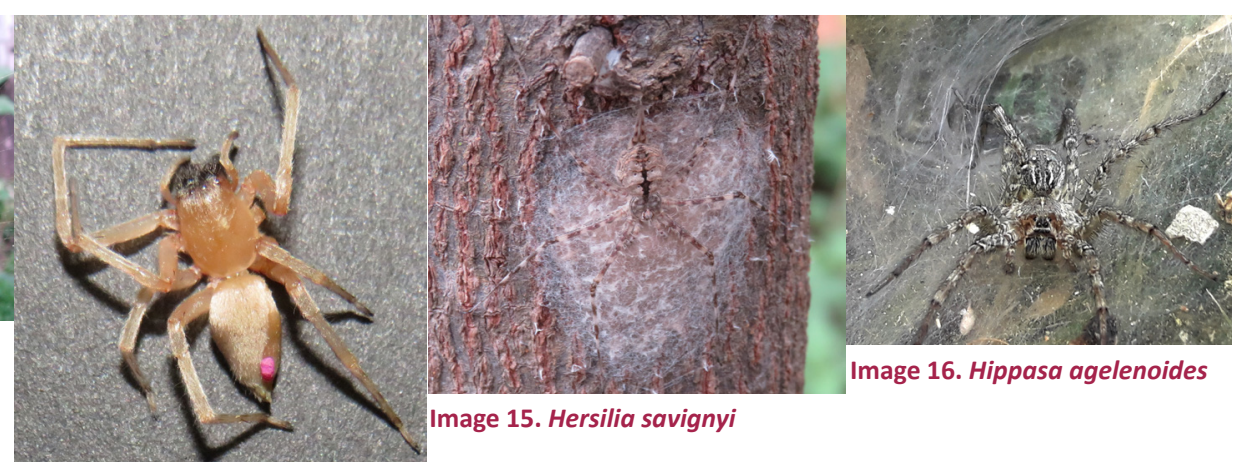

Image 16. Hippasa agelenoides

Image 14. Cheiracanthium sp. 


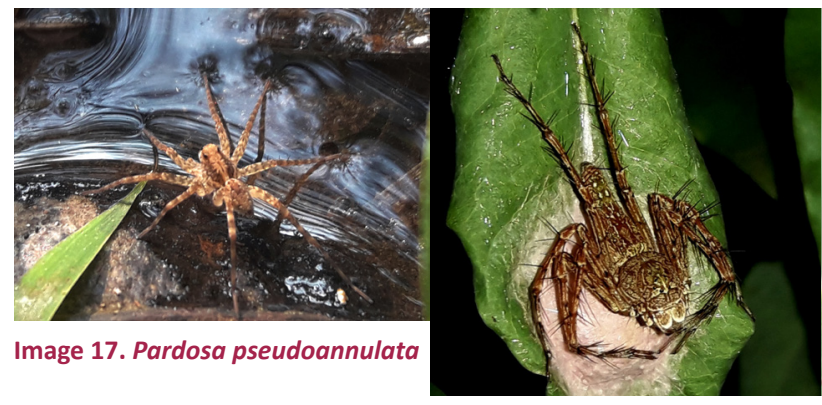

Image 18. Hamadruas sp.

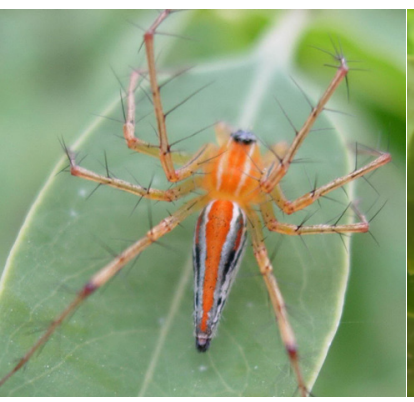

Image 19. Oxyopes sp.

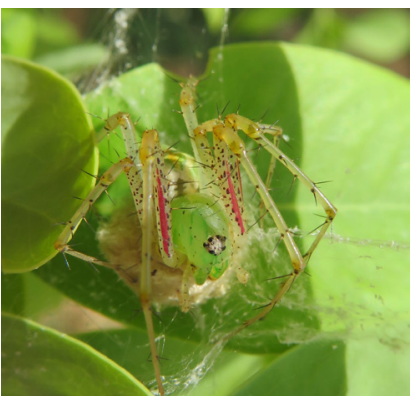

Image 20. Peucetia viridana

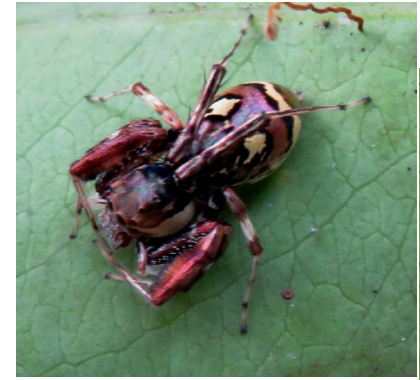

Image 21. Brettus cingulatus

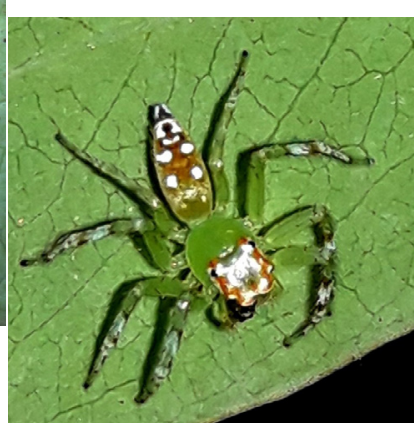

Image 22. Epeus indicus

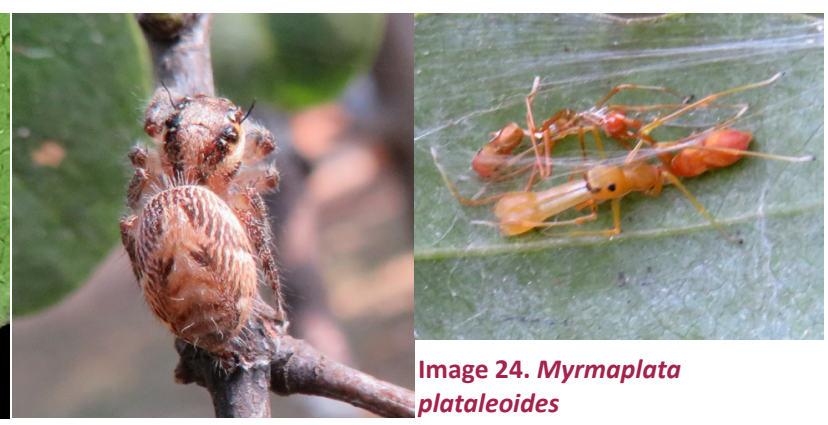

Image 23. Hyllus semicupreus

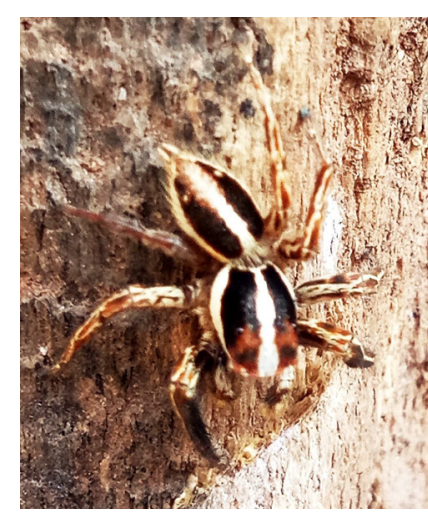

Image 25. Plexippus paykulli

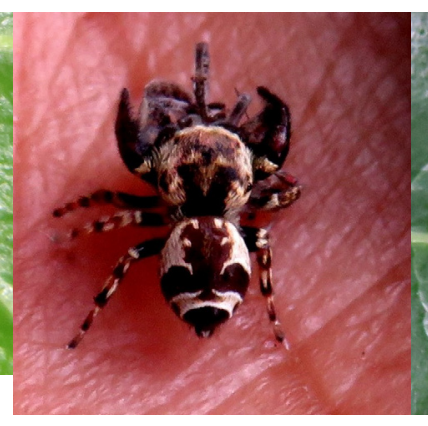

Image 27. Rhene flavigera

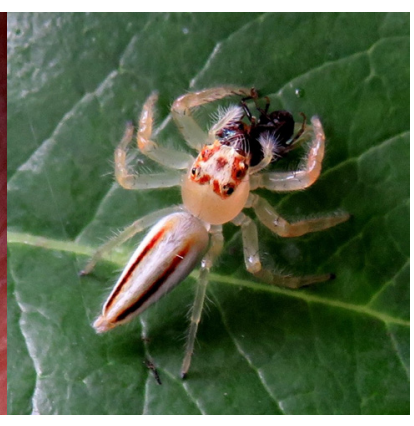

Image 28. Telamonia dimidiata

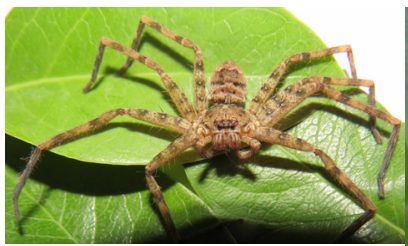

Image 29. Heteropoda venatoria

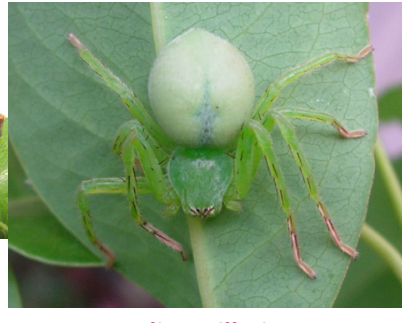

Image 30. Olios milleti

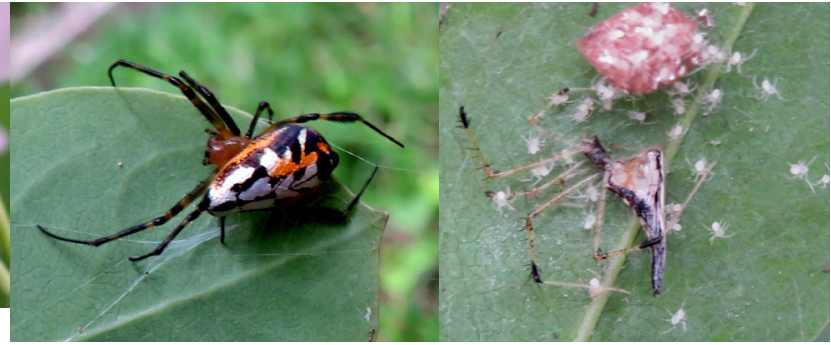

Image 32. Meotipa sahyadri

. 

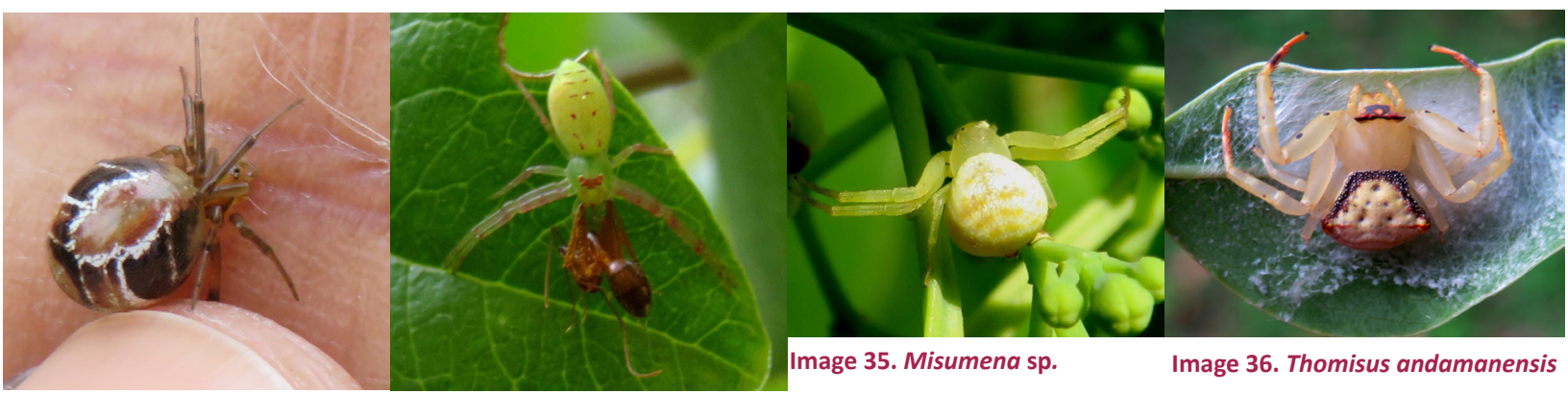

Image 35. Misumena sp.

Image 36. Thomisus andamanensis

Image 33. Nihonhimea mundula Image 34. Loxobates sp.

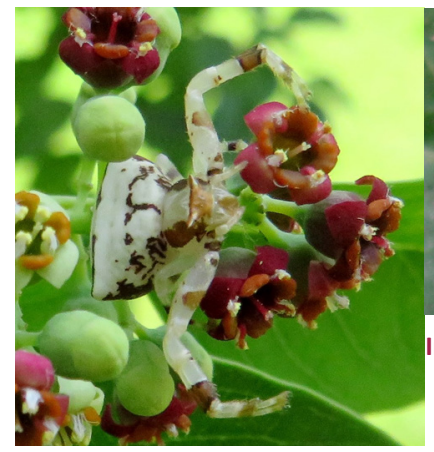

Image 37. Thomisus lobosus

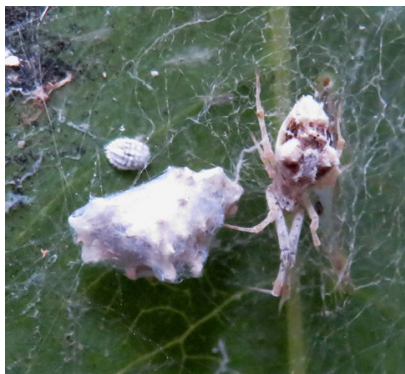

Image 41. Uloborus sp. 3

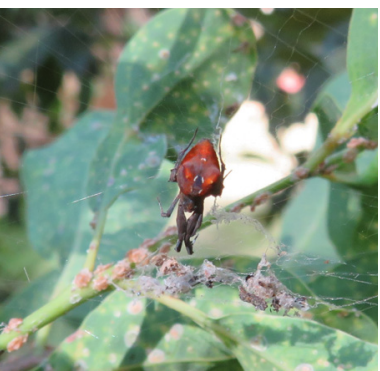

Image 42. Uloborus sp. 4

of natural undisturbed vegetation is probably crucial in the maintenance of such a healthy predatory complex (Lalnunsangi et al. 2014). Sundararaj et al. (2019) commented that the increase in incidence of stem borer is of great concern as it causes very extensive and serious damage in perennial trees like sandalwood. Once they are infested with stem borer, it paves way for the infestation of decay fungi and such infestation is carried throughout the life of sandalwood, resulting in more than one third loss of heartwood. Similarly, the wound caused by the pruning will serve as the entry point of decay fungi and other bio-deteriorating agents leading to colossal damage of wood in the standing trees. Many other reports also corroborate the concept of habitat diversification, heterogeneity, and un-pruning of plants for the balanced co-existence of pests and their natural enemies thus regulating the adverse effects of pests on the plantations (Scheidler 1990; Coddington \& Levi 1991; Whitmore et al. 2002; Tews et al. 2004; Buchholz \& Schroder 2013; Sattler et al. 2021).

\section{CONCLUSION}

Sandalwood plantations support diversity of spider fauna and they play an active role in regulating the population of phytophagous insects. The pruning of sandalwood shows an adverse effect on the diversity and abundance of spiders. Hence it is recommended not to do pruning or do the pruning only in unavoidable situations. This will increases the habitat and nutritional resources of natural enemies like spiders and facilitate to keep pest populations under control.

\section{REFERENCES}

Altieri, M.A. \& D.K. Letourneau (1984). Vegetation diversity and insect pests outbreaks. CRC Critical Reviews in Plant Sciences 2: 131-169. https://doi.org/10.1080/07352688409382193

Buchholz, S. \& M. Schroder (2013). Diversity and ecology of spider assemblages of a Mediterranean wetland complex. Journal of 


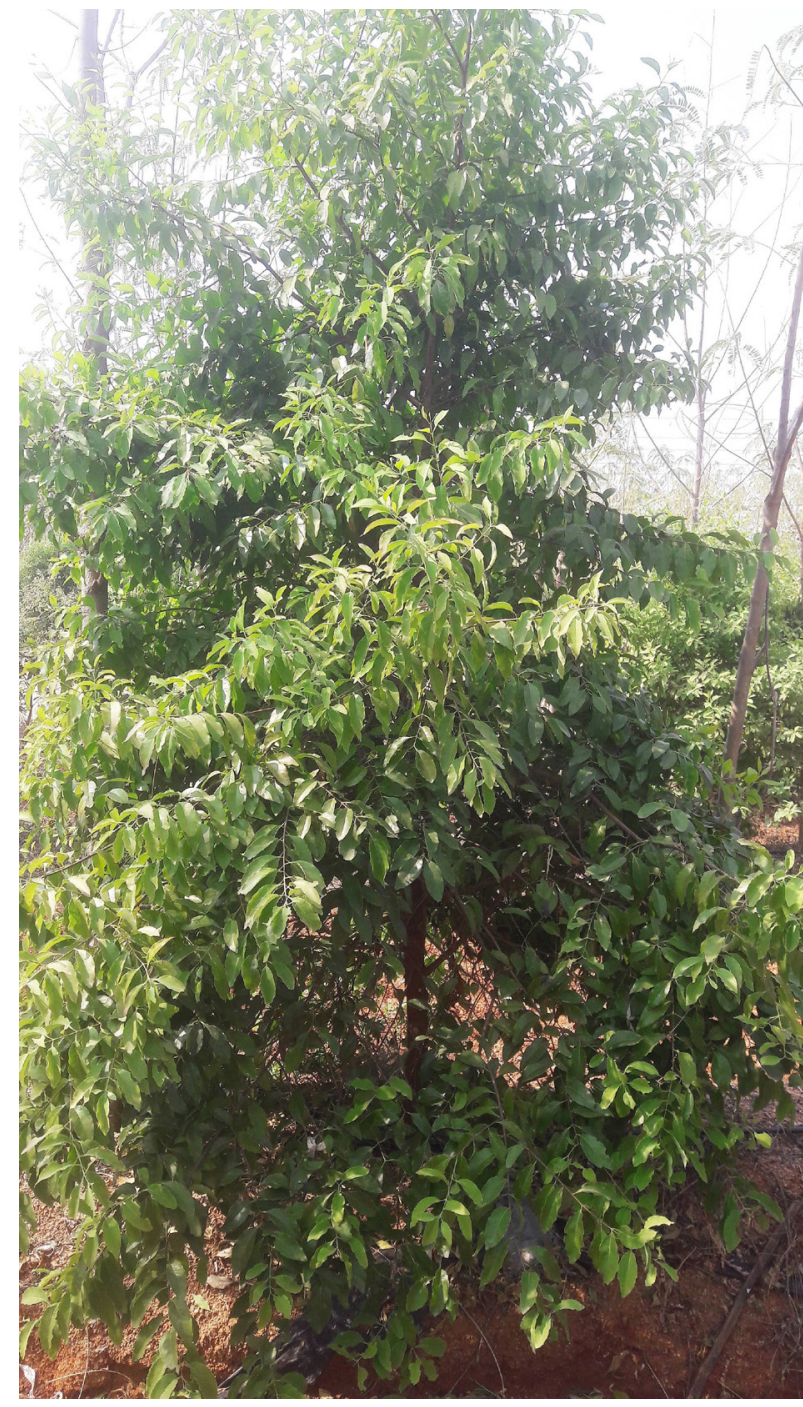

Image 43. Unpruned Sandalwood tree.

Arachnology 41: 364-373. https://doi.org/10.1636/p13-26.1

Carter, P.V. \& A.L. Rypstra (1995). Top-down effects in soya bean agroecosystems: Spider density affects herbivore damage. Oikos 72 : 433-439.

Caleb, J.T.D. \& P.M. Sankaran (2021). Araneae of India. Version 2021 , online at http://www.indianspiders.in [accessed on 18.viii.2021].

Coddington, J.A. \& H.W. Levi (1991). Systematics and evolution of spiders (Araneae). Annual Review of Ecology and Systematics 22: 565-592. https://doi.org/10.1146/annurev.es.22.110191.003025

Downie, I.S., W.L. Wilson., V.J. Abernehy., D.I. McCracken., G.N Foster., I. Ribera., A. Waterhouse \& K.J. Murphy (1999). The impact of different agricultural land-uses on epigeal spider biodiversity in Scotland. Journal of Insect conservation 3: 273-286. https://doi. org/10.1023/A:1009649222102

Foelix, R.F. (1996). Biology of Spiders. (2 ${ }^{\text {nd }}$ ed.). Oxford University Press, New York.

Greenstone, M.H. (1984). Determinants of web spider species diversity: vegetation structural diversity vs. prey availability Oecologia 62: 299-304. https://doi.org/10.1007/BF00384260

Halaj, J., D.W. Ross \& A.R. Moldenke (1998). Habitat structure and prey availability as predictors of the abundance and community organization of spiders in western Oregon forest canopies. Journal

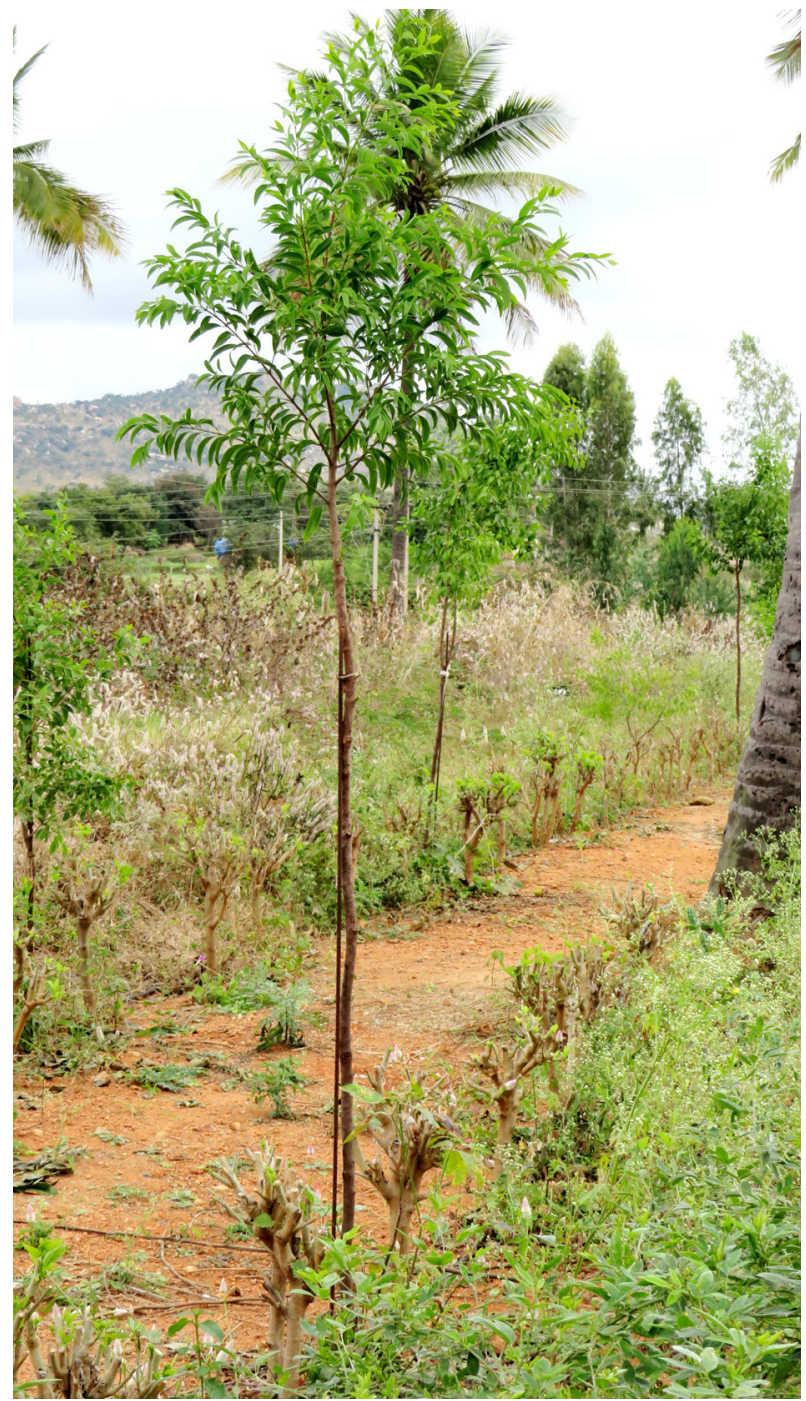

Image 44. Pruned Sandalwood tree.

of Arachnology 26: 203-220. https://andrewsforest.oregonstate. edu/sites/default/files/lter/pubs/pdf/pub2575.pdf

Lalnunsangi, R., D. Paul \& L.K. Jha (2014). Natural enemy complex of some agroforestry systems of Aizawl and their implications in insect pest management. Energy and Environment Research 4: 29-33. https://doi.org/10.5539/eer.v4n2p29

Marc, P. \& A. Canard (1997). Maintaining spider biodiversity in agroecosystems as a tool in pest control. Agriculture, Ecosystems \& Environment 62: 229-235. https://doi.org/10.1016/S01678809(96)01133-4

Metzner, H. (2021). Jumping spiders (Arachnida: Araneae: Salticidae) of the world. Accessed on 19 August 2021.https://www.jumpingspiders.com/

Oguri, H., T. Yoshida, A. Nakamura, M. Soga \& N. Hijii (2014). Vertical stratification of spider assemblages in two conifer plantations in central Japan. The Journal of Arachnology 42: 34-43. https://doi. org/10.1636/P13-73.1

Ossamy, S., S.M. Elbanna, G.M. Orabi \& F.M. Semida (2016). Assessing the potential role of spider as bioindicators in Ashtoum el Gamil Natural Protected Area, Port Said, Egypt. Indian Journal of Arachnology 5: 100-112.

Pooja, A. Anilkumar, S. Quasin, Sreelekshmi \& V.P. Uniyal (2019). 
Spider Fauna of Navdanya Biodiversity Farm, Uttarakhand, India. Indian Forester 145: 392-397.

Riechert, S.E. \& L. Bishop (1990). Prey control by an assemblage of generalist predators: Spiders in garden test systems. Ecology 71: 1441-1450. https://doi.org/10.2307/1938281

Rypstra, A.L. (1986). Web spiders in temperate and tropical forests: relative abundance and environmental correlates. The American Midland Naturalist 115: 42-51. https://doi.org/10.2307/2425835

Sandeep, S., S. Reshmi \& K.S. Jose (2020). Predatory spider faun in fruit crops of Punjab, India along with new records. Indian Journal of Agricultural Sciences 90: 1695-1701.

Sattler, C., J. Schrader, R.J. Flor, M. Keo, S. Chhun, S. Choun, H. Bar \& J. Settele (2021). Reducing pesticides and increasing crop diversification offer ecological and economic benefits for farmers - a case study in Cambodian Rice Fields. Insects 12: 267. https://doi. org/10.3390/insects12030267

Scheidler, M. (1990). Influence of habitat structure and vegetation architecture on spiders. Zoologischer Anzeiger 225: 333-340. https://doi.org/10.32800/abc.2016.39.0221

Sudhikumar, A.V., M.J. Mathew, E. Sunish \& P.A. Sebastian (2005). Seasonal variation in spider abundance in Kuttanad rice agroecosystem, Kerala, India (Araneae). European Arachnology 1: 181-190. https://doi.org/10.5829/idosi.wasj.2013.22.06.73114

Sundararaj, R., R. Rashmi, Shanbhag \& B. Lingappa (2018). Habitat diversification in the cultivation of Indian sandalwood (Santalum album Linn.): an ideal option to conserve biodiversity and manage insect pests. Journal of Biological Control 32(3): 160-164. https:// doi.org/10.18311/jbc/2018/17931

Sundararaj, R., J.J. Wilson \& D. Vimala (2019). Stem borers of Indian Sandalwood (Santalum album Linn.) in Karnataka, India. Journal of the Indian Academy of Wood Science 16: 31-35.

Sundararaj, R., R. Raja Rishi \& S. Padma (2020). Conservation of pollinators is vital for the sustainable cultivation and conservation of Indian sandalwood (Santalum album L.). Insect Environment 23: 64-67. https://nucleus.iaea.org/sites/naipc/twd/Documents/ Insect-Environment-Volume-23-Dec2020.pdf

Sunderland, K \& F. Samu (2000). Effects of agricultural diversification on the abundance, distribution and pest control potential of spiders: a review. Entomologia Experiments et Applicata 95: 1-13. https:// doi.org/10.1046/j.1570-7458.2000.00635.x

Tews, J., U. Brose, V. Grimm, K. Tielbörger, M.C. Wichmann, M. Schwager \& F. Jeltsch (2004). Animal species diversity driven by habitat heterogeneity/diversity: the importance of keystone structures. Journal of Biogeography 31: 79-92. https://doi. org/10.1046/j.0305-0270.2003.00994.x

Tikader, B.K. (1987). Hand Book of Indian Spiders. Zoological Survey of India, India.

Torres, B., O.J. Maza, P. Aguirre, L. Hinojosa \& S. Günter (2015) The Contribution of Traditional Agroforestry to Climate Change Adaptation in the Ecuadorian Amazon: The Chakra System, pp. 1973-1994. In: Filho, W.L. (ed.). Handbook of Climate Change Adaptation. Springer, Berlin/Heidelberg, Germany.

Uetz, G.W., J. Halaji \& A.B. Cady (1999). Guild structure of spiders in major crops. Journal of Arachnology 24: 270-280.

Whitmore, C., R. Slotow, T.E. Crouch \& A.S. Dippenaar-Schoeman (2002). Diversity of spiders (Araneae) in a Savanna Reserve, Northern Province, South Africa. Journal of Arachnology 30: 344356. https://doi.org/10.1636/0161-8202(2002)030[0344:DOSAIA]2 .0.CO;2

World Spider Catalog (2021). World Spider Catalog.Version 22.0. Natural History Museum Bern, online at http://wsc.nmbe.ch, Electronic version accessed on 24 March 2021.

Young, O.P. \& G.B. Edwards (1990). Spiders in United States field crops and their potential effect on crop pests. Journal of Arachnology 18(1): 1-27. 

Dr. Albert G. Orr, Griffith University, Nathan, Australia

Dr. Sameer Padhye, Katholieke Universiteit Leuven, Belgium

Dr. Nancy van der Poorten, Toronto, Canada

Dr. Kareen Schnabel, NIWA, Wellington, New Zealand

Dr. R.M. Sharma, (Retd.) Scientist, Zoological Survey of India, Pune, India

Dr. Manju Siliwal, WILD, Coimbatore, Tamil Nadu, India

Dr. G.P. Sinha, Botanical Survey of India, Allahabad, India

Dr. K.A. Subramanian, Zoological Survey of India, New Alipore, Kolkata, India

Dr. P.M. Sureshan, Zoological Survey of India, Kozhikode, Kerala, India

Dr. R. Varatharajan, Manipur University, Imphal, Manipur, India

Dr. Eduard Vives, Museu de Ciències Naturals de Barcelona, Terrassa, Spain

Dr. James Young, Hong Kong Lepidopterists' Society, Hong Kong

Dr. R. Sundararaj, Institute of Wood Science \& Technology, Bengaluru, India

Dr. M. Nithyanandan, Environmental Department, La Ala Al Kuwait Real Estate. Co. K.S.C., Kuwait

Dr. Himender Bharti, Punjabi University, Punjab, India

Mr. Purnendu Roy, London, UK

Dr. Saito Motoki, The Butterfly Society of Japan, Tokyo, Japan

Dr. Sanjay Sondhi, TITLI TRUST, Kalpavriksh, Dehradun, India

Dr. Nguyen Thi Phuong Lien, Vietnam Academy of Science and Technology, Hanoi, Vietnam

Dr. Nitin Kulkarni, Tropical Research Institute, Jabalpur, India

Dr. Robin Wen Jiang Ngiam, National Parks Board, Singapore

Dr. Lional Monod, Natural History Museum of Geneva, Genève, Switzerland.

Dr. Asheesh Shivam, Nehru Gram Bharti University, Allahabad, India

Dr. Rosana Moreira da Rocha, Universidade Federal do Paraná, Curitiba, Brasil

Dr. Kurt R. Arnold, North Dakota State University, Saxony, Germany

Dr. James M. Carpenter, American Museum of Natural History, New York, USA

Dr. David M. Claborn, Missouri State University, Springfield, USA

Dr. Kareen Schnabel, Marine Biologist, Wellington, New Zealand

Dr. Amazonas Chagas Júnior, Universidade Federal de Mato Grosso, Cuiabá, Brasil

Mr. Monsoon Jyoti Gogoi, Assam University, Silchar, Assam, India

Dr. Heo Chong Chin, Universiti Teknologi MARA (UiTM), Selangor, Malaysia

Dr. R.J. Shiel, University of Adelaide, SA 5005, Australia

Dr. Siddharth Kulkarni, The George Washington University, Washington, USA

Dr. Priyadarsanan Dharma Rajan, ATREE, Bengaluru, India

Dr. Phil Alderslade, CSIRO Marine And Atmospheric Research, Hobart, Australia

Dr. John E.N. Veron, Coral Reef Research, Townsville, Australia

Dr. Daniel Whitmore, State Museum of Natural History Stuttgart, Rosenstein, Germany.

Dr. Yu-Feng Hsu, National Taiwan Normal University, Taipei City, Taiwan

Dr. Keith V. Wolfe, Antioch, California, USA

Dr. Siddharth Kulkarni, The Hormiga Lab, The George Washington University, Washington,

D.C., USA

Dr. Tomas Ditrich, Faculty of Education, University of South Bohemia in Ceske

Budejovice, Czech Republic

Dr. Mihaly Foldvari, Natural History Museum, University of Oslo, Norway

Dr. V.P. Uniyal, Wildlife Institute of India, Dehradun, Uttarakhand 248001, India

Dr. John T.D. Caleb, Zoological Survey of India, Kolkata, West Bengal, India

Dr. Priyadarsanan Dharma Rajan, Ashoka Trust for Research in Ecology and the Environment (ATREE), Royal Enclave, Bangalore, Karnataka, India

\section{Fishes}

Dr. Neelesh Dahanukar, IISER, Pune, Maharashtra, India

Dr. Topiltzin Contreras MacBeath, Universidad Autónoma del estado de Morelos, México

Dr. Heok Hee Ng, National University of Singapore, Science Drive, Singapore

Dr. Rajeev Raghavan, St. Albert's College, Kochi, Kerala, India

Dr. Robert D. Sluka, Chiltern Gateway Project, A Rocha UK, Southall, Middlesex, UK

Dr. E. Vivekanandan, Central Marine Fisheries Research Institute, Chennai, India

Dr. Davor Zanella, University of Zagreb, Zagreb, Croatia

Dr. A. Biju Kumar, University of Kerala, Thiruvananthapuram, Kerala, India

Dr. Akhilesh K.V., ICAR-Central Marine Fisheries Research Institute, Mumbai Research

Centre, Mumbai, Maharashtra, India

Dr. J.A. Johnson, Wildlife Institute of India, Dehradun, Uttarakhand, India

\section{Amphibians}

Dr. Sushil K. Dutta, Indian Institute of Science, Bengaluru, Karnataka, India

Dr. Annemarie Ohler, Muséum national d'Histoire naturelle, Paris, France

\section{Reptiles}

Dr. Gernot Vogel, Heidelberg, Germany

Dr. Raju Vyas, Vadodara, Gujarat, India

Dr. Pritpal S. Soorae, Environment Agency, Abu Dubai, UAE.

Prof. Dr. Wayne J. Fuller, Near East University, Mersin, Turkey

Prof. Chandrashekher U. Rivonker, Goa University, Taleigao Plateau, Goa. India

Dr. S.R. Ganesh, Chennai Snake Park, Chennai, Tamil Nadu, India

Dr. Himansu Sekhar Das, Terrestrial \& Marine Biodiversity, Abu Dhabi, UAE
Birds

Dr. Hem Sagar Baral, Charles Sturt University, NSW Australia

Dr. Chris Bowden, Royal Society for the Protection of Birds, Sandy, UK

Dr. Priya Davidar, Pondicherry University, Kalapet, Puducherry, India

Dr. J.W. Duckworth, IUCN SSC, Bath, UK

Dr. Rajah Jayapal, SACON, Coimbatore, Tamil Nadu, India

Dr. Rajiv S. Kalsi, M.L.N. College, Yamuna Nagar, Haryana, India

Dr. V. Santharam, Rishi Valley Education Centre, Chittoor Dt., Andhra Pradesh, India

Dr. S. Balachandran, Bombay Natural History Society, Mumbai, India

Mr. J. Praveen, Bengaluru, India

Dr. C. Srinivasulu, Osmania University, Hyderabad, India

Dr. K.S. Gopi Sundar, International Crane Foundation, Baraboo, USA

Dr. Gombobaatar Sundev, Professor of Ornithology, Ulaanbaatar, Mongolia

Prof. Reuven Yosef, International Birding \& Research Centre, Eilat, Israel

Dr. Taej Mundkur, Wetlands International, Wageningen, The Netherlands

Dr. Carol Inskipp, Bishop Auckland Co., Durham, UK

Dr. Tim Inskipp, Bishop Auckland Co, Durham, UK

Dr. V. Gokula, National College, Tiruchirappalli, Tamil Nadu, India

Dr. Arkady Lelej, Russian Academy of Sciences, Vladivostok, Russia

Dr. Simon Dowell, Science Director, Chester Zoo, UK

Dr. Mário Gabriel Santiago dos Santos, Universidade de Trás-os-Montes e Alto Douro,

Quinta de Prados, Vila Real, Portugal

Dr. Grant Connette, Smithsonian Institution, Royal, VA, USA

Dr. M. Zafar-ul Islam, Prince Saud Al Faisal Wildlife Research Center, Taif, Saudi Arabia

Mammals

Dr. Giovanni Amori, CNR - Institute of Ecosystem Studies, Rome, Italy

Dr. Anwaruddin Chowdhury, Guwahati, India

Dr. David Mallon, Zoological Society of London, UK

Dr. Shomita Mukherjee, SACON, Coimbatore, Tamil Nadu, India

Dr. Angie Appel, Wild Cat Network, Germany

Dr. P.O. Nameer, Kerala Agricultural University, Thrissur, Kerala, India

Dr. Ian Redmond, UNEP Convention on Migratory Species, Lansdown, UK

Dr. Heidi S. Riddle, Riddle's Elephant and Wildlife Sanctuary, Arkansas, USA

Dr. Karin Schwartz, George Mason University, Fairfax, Virginia.

Dr. Lala A.K. Singh, Bhubaneswar, Orissa, India

Dr. Mewa Singh, Mysore University, Mysore, India

Dr. Paul Racey, University of Exeter, Devon, UK

Dr. Honnavalli N. Kumara, SACON, Anaikatty P.O., Coimbatore, Tamil Nadu, India

Dr. Nishith Dharaiya, HNG University, Patan, Gujarat, India

Dr. Spartaco Gippoliti, Socio Onorario Società Italiana per la Storia della Fauna "Giuseppe

Altobello", Rome, Italy

Dr. Justus Joshua, Green Future Foundation, Tiruchirapalli, Tamil Nadu, India

Dr. H. Raghuram, The American College, Madurai, Tamil Nadu, India

Dr. Paul Bates, Harison Institute, Kent, UK

Dr. Jim Sanderson, Small Wild Cat Conservation Foundation, Hartford, USA

Dr. Dan Challender, University of Kent, Canterbury, UK

Dr. David Mallon, Manchester Metropolitan University, Derbyshire, UK

Dr. Brian L. Cypher, California State University-Stanislaus, Bakersfield, CA

Dr. S.S. Talmale, Zoological Survey of India, Pune, Maharashtra, India

Prof. Karan Bahadur Shah, Budhanilakantha Municipality, Kathmandu, Nepal

Dr. Susan Cheyne, Borneo Nature Foundation International, Palangkaraja, Indonesia

Dr. Hemanta Kafley, Wildlife Sciences, Tarleton State University, Texas, USA

\section{Other Disciplines}

Dr. Aniruddha Belsare, Columbia MO 65203, USA (Veterinary)

Dr. Mandar S. Paingankar, University of Pune, Pune, Maharashtra, India (Molecular)

Dr. Jack Tordoff, Critical Ecosystem Partnership Fund, Arlington, USA (Communities)

Dr. Ulrike Streicher, University of Oregon, Eugene, USA (Veterinary)

Dr. Hari Balasubramanian, EcoAdvisors, Nova Scotia, Canada (Communities)

Dr. Rayanna Hellem Santos Bezerra, Universidade Federal de Sergipe, São Cristóvão, Brazil

Dr. Jamie R. Wood, Landcare Research, Canterbury, New Zealand

Dr. Wendy Collinson-Jonker, Endangered Wildlife Trust, Gauteng, South Africa

Dr. Rajeshkumar G. Jani, Anand Agricultural University, Anand, Gujarat, India

Dr. O.N. Tiwari, Senior Scientist, ICAR-Indian Agricultural Research Institute (IARI), New

Delhi, India

Dr. L.D. Singla, Guru Angad Dev Veterinary and Animal Sciences University, Ludhiana, India

Dr. Rupika S. Rajakaruna, University of Peradeniya, Peradeniya, Sri Lanka

Dr. Bahar Baviskar, Wild-CER, Nagpur, Maharashtra 440013, India

Reviewers 2018-2020

Due to pausity of space, the list of reviewers for 2018-2020 is available online.
The opinions expressed by the authors do not reflect the views of the Journal of Threatened Taxa, Wildlife Information Liaison Development Society, Zoo Outreach Organization, or any of the partners. The journal, the publisher, the host, and the partners are not responsible for the accuracy of the political boundaries shown in the maps by the authors.

\footnotetext{
Print copies of the Journal are available at cost. Write to:

The Managing Editor, JoTT,

c/o Wildlife Information Liaison Development Society,

No. 12, Thiruvannamalai Nagar, Saravanampatti - Kalapatti Road,

Saravanampatti, Coimbatore, Tamil Nadu 641035, India

ravi@threatenedtaxa.org
} 


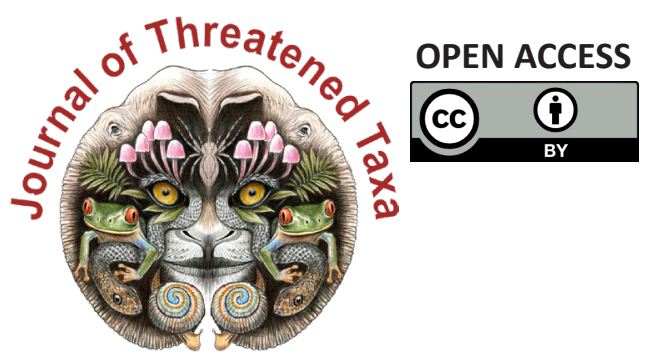

www.threatenedtaxa.org

The Journal of Threatened Taxa (JoTT) is dedicated to building evidence for conservation globally by publishing peer-reviewed articles online every month at a reasonably rapid rate at www.threatenedtaxa.org. All articles published in JoTT are registered under Creative Commons Attribution 4.0 International License unless otherwise mentioned. JoTT allows allows unrestricted use, reproduction, and distribution of articles in any medium by providing adequate credit to the author(s) and the source of publication.

\section{ISSN $0974-7907$ (Online) | ISSN $0974-7893$ (Print)}

\section{October 2021 | Vol. 13 | No. 12 | Pages: 19675-19886 \\ Date of Publication: 26 October 2021 (Online \& Print) DOI: 10.11609/jott.2021.13.12.19675-19886}

Articles

Roosting habits and habitats of the Indian Flying Fox Pteropus medius Temminck, 1825 in the northern districts of Tamil Nadu, India

- M. Pandian \& S. Suresh, Pp. 19675-19688

Diversity and distribution of avifauna at Warathenna-Hakkinda Environmental Protection Area in Kandy, Sri Lanka

- Dinelka Thilakarathne, Tithira Lakkana, Gayan Hirimuthugoda, Chaminda Wijesundara \& Shalika Kumburegama, Pp. 19689-19701

Grass species composition in tropical forest of southern India

- M. Ashokkumar, S. Swaminathan \& R. Nagarajan, Pp. 19702-19713

\section{Communications}

Habitat use and conservation threats to Wild Water Buffalo Bubalus arnee (Mammalia: Artiodactyla: Bovidae) in Koshi Tappu Wildlife Reserve, Nepal

- Reeta Khulal, Bijaya Neupane, Bijaya Dhami, Siddhartha Regmi, Ganesh Prasad Tiwari \& Manita Parajuli, Pp. 19714-19724

Get my head around owls: people perception and knowledge about owls of Andaman Islands

- Shanmugavel Sureshmarimuthu, Santhanakrishnan Babu, Nagaraj Rajeshkumar \& Honnavalli Nagaraj Kumara, Pp. 19725-19732

Abundance and diversity of threatened birds in Nangal Wetland, Punjab, India - Rajwinder Kaur \& Onkar Singh Brraich, Pp. 19733-19742

Evaluation of fish diversity and abundance in the Kabul River with comparisons between reaches above and below Kabul City, Afghanistan

- Ugyen Kelzang, Ahmad Farid Habibi \& Ryan J. Thoni, Pp. 19743-19752

New record of Myrmarachne melanocephala MacLeay, 1839 (Araneae: Salticidae) from Jharkhand, India and biogeographical implications of the co-occurrence of its ant model Tetraponera rufonigra Jerdon, 1851

- Rahul Kumar, Mirtunjay Sharma \& Ajay Kumar Sharma, Pp. 19753-19761

Diversity of spiders (Arachnida: Araneae) and the impact of pruning in Indian sandalwood plantations from Karnataka, India

-S. Padma 1 \& R. Sundararaj, Pp. 19762-19772

New records of cheilostome Bryozoa from the eastern coast of India encrusting on the exoskeleton of live horseshoe crabs of Indian Sundarbans

- Swati Das, Maria Susan Sanjay, Basudev Tripathy, C. Venkatraman \& K.A. Subramanian, Pp. 19773-19780

On the pteridophytes of Bherjan-Borajan-Padumoni Wildlife Sanctuary, Assam, India - Pranjal Borah \& Jayanta Barukial, Pp. 19781-19790

Population status of Heritiera fomes Buch.-Ham., a threatened species from Mahanadi Mangrove Wetland, India

- Sudam Charan Sahu, Manas Ranjan Mohanta \& N.H. Ravindranath, Pp. 19791-19798

Additions to the lichenized and lichenicolous fungi of Jammu \& Kashmir from Kishtwar High Altitude National Park

- Vishal Kumar, Yash Pal Sharma, Siljo Joseph, Roshinikumar Ngangom \& Sanjeeva Nayaka, Pp. 19799-19807

\section{Short Communications}

Is release of rehabilitated wildlife with embedded lead ammunition advisable? Plumbism in a Jaguar Panthera Onca (Mammalia: Carnivora: Felidae), survivor of gunshot wounds - Eduardo A. Díaz, Carolina Sáenz, E. Santiago Jiménez, David A. Egas \& Kelly Swing, Pp. 19808-19812

New record of the Sewing Needle Zipper Loach Paracanthocobitis linypha Singer \& Page, 2015 (Teleostei: Cypriniformes: Nemacheilidae) from the Chindwin drainage of Manipur, India

- Yumnam Rameshori, Yengkhom Chinglemba \& Waikhom Vishwanath, Pp. 19813-19817

Field identification characters to diagnose Microhyla mukhlesuri from closely related M. mymensinghensis (Amphibia: Microhylidae) and range extension of $M$. mukhlesuri up to West Bengal State, India

- Suman Pratihar \& Kaushik Deuti, Pp. 19818-19823
First report of Scipinia horrida (Stål) (Heteroptera: Reduviidae) from Assam, with comments on related genus Irantha Stål

- Anjana Singha Naorem, Santana Saikia, Anandita Buragohain, Rubina Azmeera Begum, Swapnil S. Boyane \& Hemant V. Ghate, Pp. 19824-19830

Flesh fly (Diptera: Sarcophagidae): male terminalia, diversity and expanded geographical distribution from India

- Kanholi Sreejith, Shuvra Kanti Sinha, Santanu Mahato \& Edamana Pushpalatha, Pp. 1983119836

Checklist of moths (Heterocera) of Tadong, Sikkim, India

- Prayash Chettri, Yuki Matsui, Hideshi Naka \& Archana Tiwari, Pp. 19837-19848

New distribution records of Begonia L., B. murina Craib and B. poilanei Kiew (Begoniaceae: Cucurbitales) for Laos

- Phongphayboun Phonepaseuth, Phetlasy Souladeth, Soulivanh Lanorsavanh, Shuichiro Tagane, Thyraphon Vongthavone \& Keooudone Souvannakhoummane Pp. 19849-19854

Notes

A recent sighting of the Stripe-backed Weasel Mustela strigidorsa (Mammalia: Carnivora: Mustelidae) in Hkakabo Razi Landscape, Myanmar

- Sai Sein Lin Oo, Tun Tun, Kyaw Myo Naing \& Paul Jeremy James Bates, Pp. 19855-19859

Are the uplifted reef beds in North Andaman letting nesting Olive Ridley Sea Turtle Lepidochelys olivacea stranded?

- Nehru Prabakaran, Anoop Raj Singh \& Vedagiri Thirumurugan, Pp. 19860-19863

First record of the orb-weaving spider Araneus tubabdominus Zhu \& Zhang, 1993 (Araneae: Araneidae) from India

- Souvik Sen, John T.D. Caleb \& Shelley Acharya, Pp. 19864-19866

The genus Catapiestus Perty, 1831 (Coleoptera: Tenebrionidae: Cnodalonini) from Arunachal Pradesh with one new record to India

- V.D. Hegde \& Sarita Yadav, Pp. 19867-19869

Rediscovery and extended distribution of Indigofera santapaui Sanjappa (Leguminosae: Papilionoideae) from the states of Maharashtra and Gujarat, India

- Kumar Vinod Chhotupuri Gosavi, Sanjay Gajanan Auti, Sharad Suresh Kambale \& Munivenkatappa Sanjappa, Pp. 19870-19873

Additional distribution records of Ceropegia anjanerica, an endemic and 'Endangered' lantern flower of the northern Western Ghats, India

- Samir Shrikant Maity, Ajay Natha Gangurde, Sharad Suresh Kambale, Avinash Ramchandra Gholave, Avinash Asraji Adsul, Ganesh Babaso Pawar \& Kumar Vinod Chhotupuri Gosavi, Pp. 19874-19877

Notes on the extended distribution of Impatiens megamalayana, a recently described balsam in Western Ghats, India

- Anoop P. Balan \& A.J. Robi, Pp. 19878-19883

Book Review

A look over on the scented tree of India (Santalum album - S. Suresh Ramanan \& A. Arunachalam, Pp. 19884-19886
Publisher \& Host
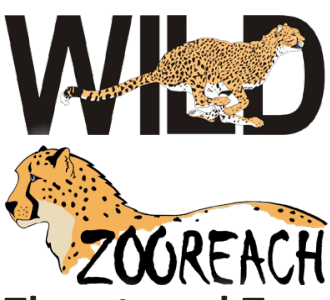

Threatened Taxa 